\title{
Edukasi Pencegahan Kanker Serviks Secara Primer \& Sekunder Bagi Dosen FKIK UMY
}

\author{
Ivanna Beru Brahmana1 \\ 1 Bagian Obstetri \& Ginekologi, \\ Program Studi Pendidikan Dokter, Fakultas Kedokteran \& Ilmu Kesehatan, Universitas Muhammadiyah Yogyakarta, \\ J. Brawijaya, Tamantirto, Kasihan, Bantul, DI Yogyakarta 55183, \\ Telp 0274387656 Ext 212 \\ Email: ivanna@umy.ac.id \\ DOI: $10.18196 / p p m .34 .63$
}

\begin{abstract}
Abstrak
Kanker serviks merupakan jenis kanker yang menduduki peringkat tertinggi yang diderita wanita Indonesia. Tidak kurang dari 15.000 kasus kanker serviks terjadi setiap tahunnya di Indonesia. Pencegahan kanker serviks dilakukan secara primer dan sekunder. Pencegahan primer dengan vaksinasi Human Papilloma Virus (HPV), yang sekunder dengan pemeriksaan Pap Smear dan Inspeksi Visual Asam Asetat (IVA). FKIK UMY sebagian besar dosen pengampu adalah dosen-dosen wanita. Memberikan edukasi tentang kanker serviks dengan upaya pencegahan primer dan sekunder. Bentuk pengabdian berupa: minisimposium dan tanya jawab tentang kanker serviks, pemeriksaan Pap Smear, dan vaksinasi HPV. Peserta awal direncanakan terbatas dosen putri di FKIK UMY, bertambah dengan hadirnya dosen non FKIK. Minisimposium dihadiri 55 (55/101) dosen putri FKIK UMY dan non FKIK, dari 101 peserta vaksinasi. Peserta vaksinasi adalah ibu dosen beserta putrinya, bisa dikatakan hampir 100\% peserta vaksinasi terwakilkan. Pemeriksaan Pap Smear dilakukan di AMC 74,5\% (38/51) dan 25,5\% (13/51) di luar AMC. Sebanyak 39,47\% (15/38) menyampaikan rasa takut sebagai alasan utama tidak melakukan pemeriksaan Pap Smear, diikuti rasa malu 26,32\% (10/38), tidak sempat atau tidak punya waktu luang untuk melakukan pemeriksaan sebanyak 21,05\% (8/38), dan lain-lain sebanyak 13,16\% (5/38). Seratus persen peserta yang dimintai pendapatnya secara acak menyampaikan bahwa kegiatan pengabdian ini sangat bermanfaat, dan kegiatan serupa perlu dilanjutkan untuk lingkup yang lebih luas. Simpulan berupa edukasi pencegahan kanker serviks bagi dosen wanita sangat perlu dilakukan. Pemeriksaan Pap Smear dan vaksinasi HPV perlu dilakukan lebih menyeluruh di lingkungan kampus UMY. Luaran pengabdian adalah publikasi di jurnal nasional
\end{abstract}

Kata Kunci: kanker serviks, pencegahan primer, pencegahan sekunder, Pap Smear, vaksinasi HPV.

\section{Pendahuluan}

Prevalensi penyakit kanker di Indonesia menurut Riskesdas 2007 sebesar 4,3\%o berdasarkan diagnosis yang ditulis oleh tenaga kesehatan. Urutan 10 besar provinsi dengan prevalensi kanker tertinggi hingga terendah di Indonesia, adalah: Provinsi Jawa Tengah, Jawa Barat, Jawa Timur, DKI Jakarta, Banten, Sulawesi Selatan, Sumatra Utara, DI Yogyakarta, Lampung, dan Sumatra Barat (Dewi M., 2017). Prevalensi kanker di Indonesia sebesar 1,4\% untuk semua umur penduduk. Tiga provinsi dengan prevalensi kanker tertinggi di Indonesia adalah DI Yogyakarta 4,1\%, Jawa Tengah 2,1\%, dan Bali 2,0\% (Pusat Data dan Informasi, 2015). Kanker serviks merupakan jenis kanker yang menduduki peringkat tertinggi yang diderita wanita Indonesia. Tidak kurang dari 15.000 kasus kanker serviks terjadi setiap tahunnya di Indonesia. (Mariana R, 2019).

Dalam rangka memperingati Hari Kanker Sedunia pada tahun 2019, Kementerian Kesehatan RI menyebutkan bahwa angka kejadian kanker tertinggi pada wanita Indonesia adalah kanker payudara, diikuti oleh kanker serviks. Kanker payudara diderita oleh 42,1 per 100.000 penduduk, dengan rata-rata kematian 17 per 100.000 penduduk. Kanker serviks diderita oleh 23,4 per 100.000 penduduk, dengan rata-rata kematian 13,9 per 100.000 penduduk (https://www.kemkes.go.id/article/view/19020100003/hari-kanker-sedunia-2019.html. Diakses pada tanggal 9 Oktober 2020). 
Human Papilloma Virus (HPV) merupakan virus penyebab kanker serviks, oleh karena 99,7\% kasus yang berkembang menjadi kanker serviks terdeteksi adanya virus HPV. Pencegahan primer pada kanker serviks dengan melakukan suntikan vaksinasi HPV. Pencegahan sekunder pada kanker serviks dengan pemeriksaan Pap Smear dan pemeriksaan Inspeksi Visual Asam Asetat (IVA) (Andrijono, 2016).

Hasil deteksi dini kanker serviks di Indonesia pada tahun 2018 yang dilakukan pada wanita berusia 30-50 tahun, didapatkan 77.969 IVA positif dan 3.563 curiga kanker serviks (Kementerian Kesehatan RI, 2019). Pada tahun 2019 data serupa didapatkan 84.1859 IVA positif dan 5.015 curiga kanker serviks (Kementerian Kesehatan RI, 2020). Data Balitbangkes Kemenkes RI pada tahun 2016 menyatakan bahwa wanita Indonesia berusia 25-64 tahun baru sekitar 3,53\% yang melakukan pemeriksaan IVA dan sekitar 7,71\% yang melakukan pemeriksaan Pap Smear. Beberapa negara maju yang telah melakukan upaya pencegahan kanker serviks dengan baik, 65\% kasus kanker serviks menurun dalam kurun waktu 40 tahun setelah pelaksanaan vaksinasi (Dewi M., 2017). Angka 2,45\% menunjukkan rendahnya cakupan deteksi dini kanker leher rahim dan payudara di Indonesia. Target yang ingin dicapai dalam cakupan deteksi dini tersebut sebesar 50\% perempuan usia 30-50 tahun selama 5 tahun (Wahidin M., 2015).

Fakultas Kedokteran dan Ilmu Kesehatan, Universitas Muhammadiyah Yogyakarta (FKIK UMY) sebagai institusi pendidikan di bidang kesehatan sebagian besar dosen pengampu adalah dosen-dosen wanita. Perlunya menggali seberapa besar pengetahuan, kepedulian pencegahan kanker serviks dengan pemeriksaan Pap Smear dan penyuntikan vaksinasi HPV pada dosen-dosen wanita FKIK UMY, maka pengabdian ini diselenggarakan oleh pengabdi.

\section{Metode Pelaksanaan}

Pelaksanaan pengabdian dijadualkan dalam bentuk 3 jenis kegiatan, yaitu: minisimposium dan tanya jawab, pemeriksaan Pap Smear, dan penyuntikan vaksinasi pencegahan kanker serviks. Peserta pengabdian direncanakan dari dosen-dosen wanita FKIK UMY beserta putriputrinya, yang ternyata bertambah peminat dari beberapa dosen wanita di luar FKIK UMY. Penentuan waktu dan tempat pelaksanaan pengabdian di salah satu ruangan di gedung FKIK UMY, yang memudahkan ibu-ibu dosen menghadiri acara, di antara kesibukan kegiatan masingmasing.

Adapun langkah-langkah pelaksanaan kegiatan adalah sebagai berikut:

\section{Perencanaan}

Perencanaan tema kegiatan, sasaran peserta, jumlah peserta, waktu dan tempat pelaksanaan, kepanitiaan, merupakan hal yang mutlak dilakukan demi terlaksananya kegiatan dengan baik dan lancar. Respon dari pejabat fakultas beserta jajarannya sangat mendorong terlaksananya kegiatan ini, makin membuat antusias tim yang tergabung dalam kepanitiaan.

Tema kegiatan yang diusung tentang kanker serviks dan metode pencegahan primer dan sekunder. Sasaran peserta adalah dosen-dosen wanita di lingkungan FKIK UMY, beserta putriputrinya, minimal berusia 9 tahun, dan maksimal berusia 55 tahun. Waktu dan tempat pelaksanaan kegiatan ditentukan segera, setelah matangnya bentuk kegiatan, dengan bertempat di salah satu ruangan di gedung FKIK UMY, yang memudahkan ibu-ibu dosen untuk menghadiri acara.

\section{Implementasi}

Pengabdian masyarakat ini telah terlaksana dengan lancar dengan 3 jenis kegiatan, yaitu minisimposium dan tanya jawab, pemeriksaan Pap Smear, dan penyuntikan vaksinasi pencegahan kanker serviks. 
Gambaran umum tentang pelaksanaan program kegiatan disajikan dalam bentuk diagram alir sebagai berikut:

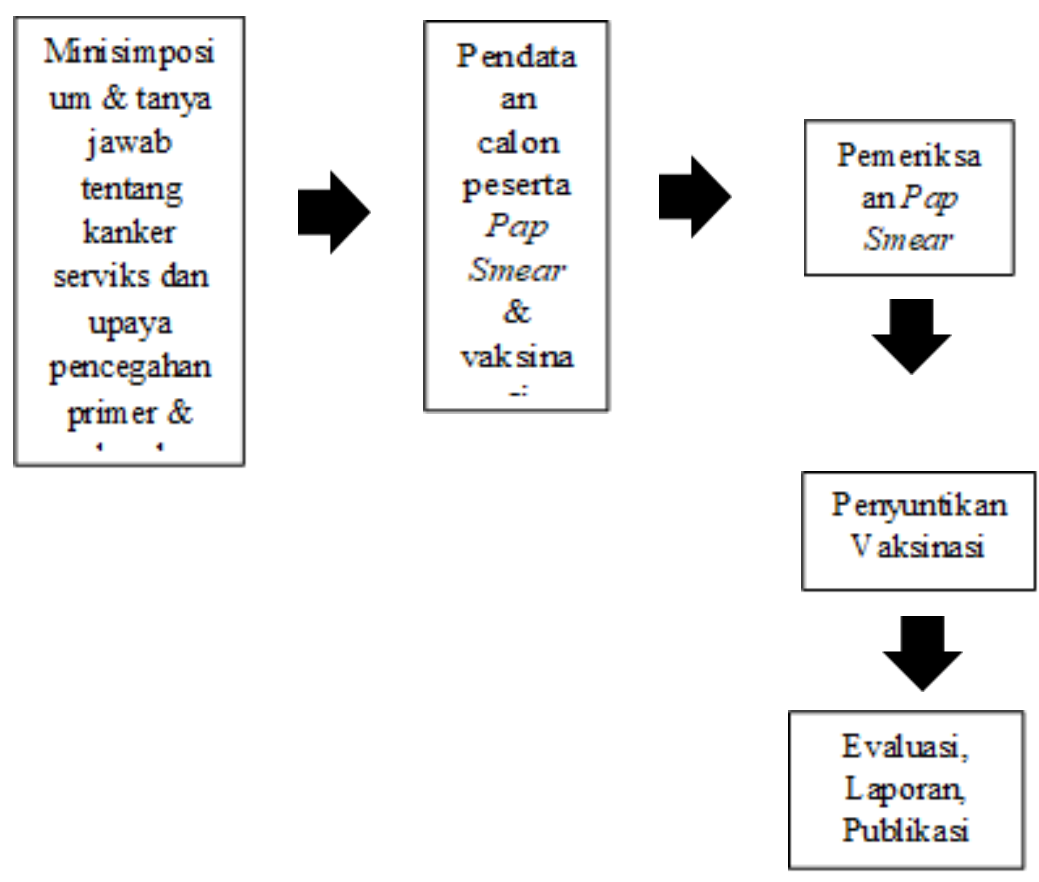

\section{Hasil dan Pembahasan}

Ketiga kegiatan dalam pengabdian ini, yakni: minisimposium dan tanya jawab, pemeriksaan Pap Smear, dan penyuntikan vaksinasi HPV dapat berjalan dengan lancar. Kegiatan pertama berupa minisimposium dan tanya jawab dilaksanakan pada Hari Jum'at, 13 Maret 2020 di Ruang Amphi Theatre B, Gedung Siti Walidah Lantai II, FKIK UMY. Pemateri dalam minisimposium ini adalah dr. Ivanna Beru Brahmana, SpOG(K), sebagai Dokter Spesialis Obstetri dan Ginekologi FKIK UMY yang memberikan materi tentang kanker serviks dan upaya pencegahannya dan dr. Indrayanti, Sp.PA, sebagai Dokter Spesialis Patologi Anatomi FKIK UMY, yang memberikan materi tentang perjalanan sel kanker serviks dan gambaran patologi anatominya. Kegiatan minisimposium dan tanya jawab dihadiri sebanyak 55 peserta. Antusiasme peserta terlihat dari banyaknya pertanyaan yang disampaikan. Kebanyakan merasa tertarik dengan pemeriksaan Pap Smear, dimana sebagian ibu-ibu dosen belum pernah melakukan pemeriksaan Pap Smear sebelumnya. Rasa takut, malu, atau tidak sempat meluangkan waktu, merupakan alasan yang paling banyak disampaikan oleh ibu-ibu dosen dalam permasalahan mengapa belum rutin melakukan pemeriksaan Pap Smear.

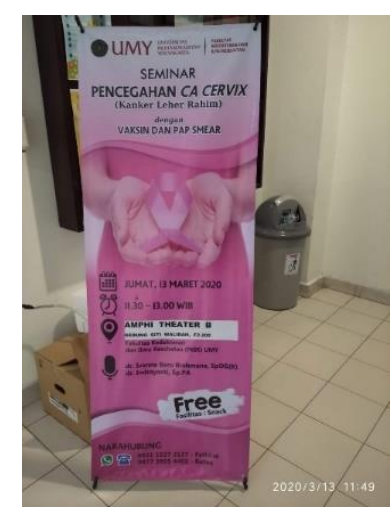




\section{7}

Gambar 1. Banner Pelaksanaan Minisimposium.

Sumber: dokumen penulis.

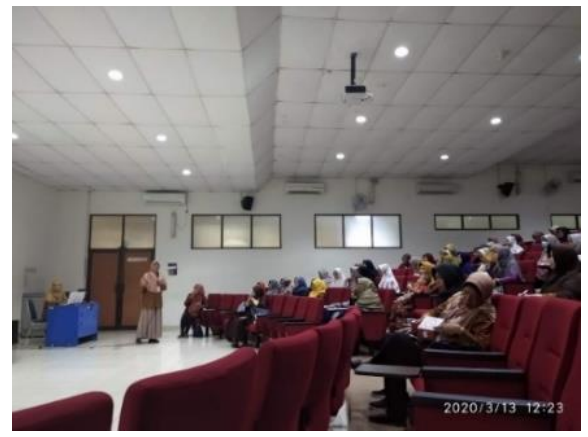

Gambar 2. Pemateri 1.

Sumber: dokumen penulis

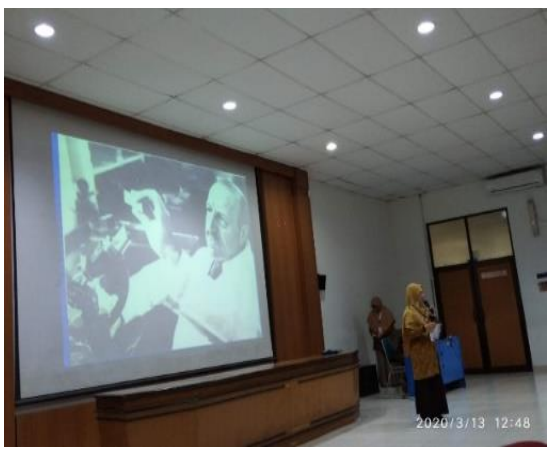

Gambar 3. Pemateri 2.

Sumber: dokumen penulis

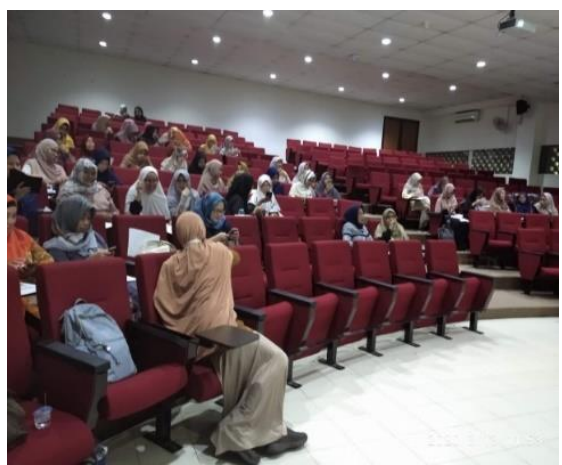

Gambar 4. Peserta Minisimposium.

Sumber: dokumen penulis.

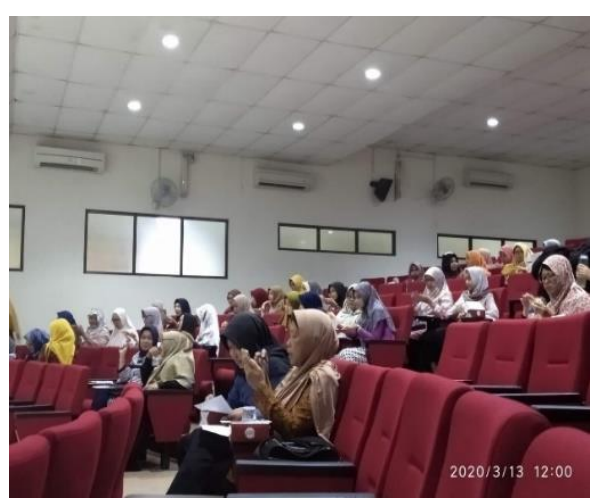

Gambar 5. Peserta Minisimposium. 
Sumber: dokumen penulis.

Gambar-gambar di atas adalah foto-foto kegiatan pengabdian yang diambil dari dokumen penulis. Gambar 1 menunjukkan banner pelaksanaan minisimposium dan tanya jawab, yang dilaksanakan pada Hari Jumat, 13 Maret 2020, jam 11.30-13.00 WIB, di ruang Amphi Theatre B, Gedung Siti Walidah Lantai II, FKIK UMY. Gambar 2 menunjukkan saat pemateri 1 yaitu dr. Ivanna Beru Brahmana, $\operatorname{SpOG}(\mathrm{K})$ mengupas materi tentang kanker serviks dan upaya pencegahannya. Gambar 3 menunjukkan saat pemateri 2 yaitu dr. Indrayanti, SpPA menyampaikan materi tentang perjalanan sel kanker serviks dan gambaran patologi anatominya. Gambar 4 dan 5 menunjukkan peserta pengabdian yang terdiri dari ibu-ibu dosen FKIK UMY dan non-FKIK UMY.

\begin{tabular}{lcc}
\multicolumn{3}{c}{ Tabel 1. Rincian Jumlah Peserta Pengabdian } \\
\hline Peserta Pengabdian & $\begin{array}{l}\text { Jumlah } \\
\text { (n) }\end{array}$ & Persentase (\%) \\
\hline Kegiatan 1: & $5 \xi$ & 54,45 \\
Peserta Minisimposium & 51 & 50,50 \\
Sudah menikah & 5( & 49,50 \\
Belum menikah & 1( & 100,00 \\
Total & & \\
Kegiatan 2: & $3 \varepsilon$ & 74,51 \\
Peserta Pap Smear Internal & 12 & 25,49 \\
Peserta Pap Smear Eksternal & 51 & 100,00 \\
Total & & \\
Kegiatan 3: & 1( & 100,00 \\
$\quad$ Peserta Vaksinasi & 1( & 100,00 \\
\hline
\end{tabular}

Tabel 1 menunjukkan rincian peserta pengabdian dalam tiap kegiatan pengabdian. Kegiatan pertama berupa minisimposium dan tanya jawab diikuti oleh 55 peserta atau $54,46 \%$ $(55 / 101)$ dari total peserta vaksinasi. Jumlah peserta yang sudah menikah sebanyak 51 peserta. Untuk itu 51 ibu ini melakukan pemeriksaan Pap Smear terlebih dahulu, sebelum melakukan penyuntikan vaksinasi. Sejumlah 74,51\% (38/51) peserta melakukan pemeriksaan Pap Smear di Poliklinik Obsgin AMC, yang disebut sebagai peserta pemeriksaan Pap Smear internal. Peserta pemeriksaan Pap Smear eksternal adalah mereka yang sudah melakukan pemeriksaan Pap Smear selain di AMC, sebanyak 25,49\% (13/51). Hal ini sejalan dengan pengabdian di Klinik Mariana, dari 32 peserta pengabdian, baru 10 peserta yang sudah pernah melakukan pemeriksaan Pap Smear dan IVA sebelumnya (Sembiring R. dan Panggabean R.D.E., 2020). Hasil Pap Smear 51 peserta pengabdian normal, dilanjutkan kegiatan ketiga berupa penyuntikan vaksinasi HPV.

Jumlah peserta yang belum menikah sebanyak 50 peserta. Mereka yang belum menikah bisa langsung mendaftar sebagai peserta penyuntikan vaksinasi HPV. Peserta yang berusia 9-12 tahun menjalani penyuntikan vaksinasi sebanyak dua kali, yaitu suntikan pertama pada bulan ke-0, dan suntikan kedua pada bulan ke-6. Peserta yang berusia lebih dari 12 tahun, baik yang belum menikah maupun yang sudah menikah, menjalani penyuntikan vaksinasi sebanyak tiga kali. Jadual penyuntikan pertama pada bulan ke-0, suntikan kedua pada bulan ke-2, dan suntikan ketiga atau terakhir pada bulan ke-6. Vaksinasi pencegahan kanker serviks yang digunakan adalah vaksin tipe quadrivalen.

Sebagian besar peserta melakukan suntikan vaksinasi pertama pada akhir bulan Maret 2020. Kondisi pandemi Covid-19 yang terjadi tiba-tiba, di mana protokol pencegahan penularannya dianjurkan untuk melakukan stay at home dan social distancing, menjadi kendala yang tidak terduga dalam pelaksanaan penyuntikan vaksinasi ini. Beberapa peserta penyuntikan vaksinasi baru melakukan penyuntikan vaksinasi pertamanya pada bulan April dan Mei 2020, bahkan ada sekitar 3,96\% (4/101) peserta yang baru melakukan penyuntikan vaksinasi pertama 
pada bulan Oktober 2020, oleh karena kondisi pandemi ini yang mana belum berani keluar rumah bila memang tidak keperluan mendesak. Hal tersebut merupakan kendala yang dialami dalam kegiatan pengabdian di masa pandemi ini, namun secara umum, lebih dari $90 \%$ kegiatan vaksinasi sudah berhasil dilaksanakan.

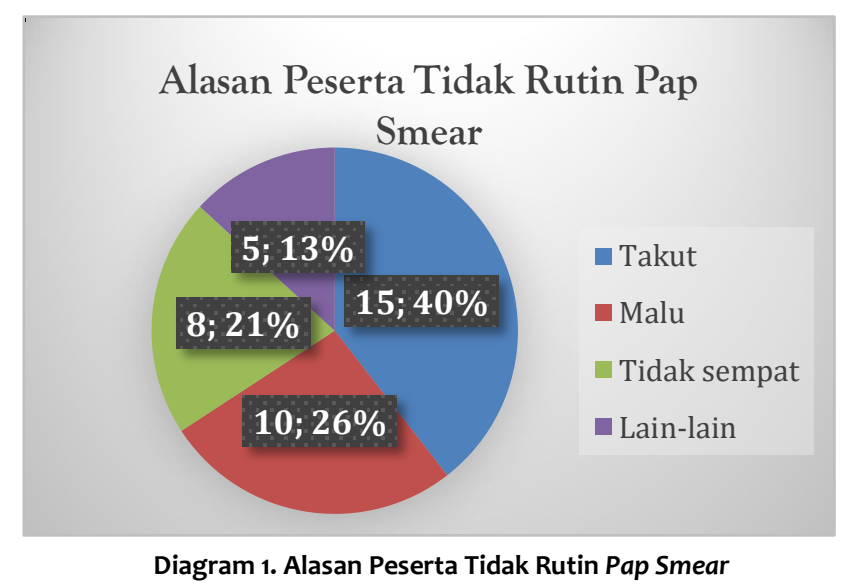

Diagram 1 menunjukkan alasan peserta minisimposium dan tanya jawab belum melakukan pemeriksaan Pap Smear dengan rutin. Sebanyak 39,47\% (15/38) menyampaikan rasa takut sebagai alasan utama tidak melakukan pemeriksaan Pap Smear. Takut terhadap cara pemeriksaan, maupun takut terhadap hasil yang didapatkan nanti. Alasan berikutnya adalah rasa malu 26,32\% (10/38), tidak sempat atau tidak punya waktu luang untuk melakukan pemeriksaan sebanyak 21,05\% (8/38), dan lain-lain sebanyak 13,16\% (5/38). Alasan-alasan tersebut sesuai dengan penelitian kualitatif yang dilakukan oleh Syaiful, dkk., bahwa tidak dilakukannya pemeriksaan Pap Smear oleh bidan-bidan yang menjadi subyek penelitiannya dikarenakan: malu, takut, merasa belum ada keluhan, kesterilan alat kesehatan, malas, dan faktor biaya Syaiful dkk., 2018).

Pengabdian ini diharapkan dapat memberikan motivasi pada ibu-ibu dosen FKIK UMY dan non FKIK UMY untuk dapat melakukan pemeriksaan Pap Smear secara rutin. Hal ini sesuai dengan pengabdian yang dilakukan oleh Julaecha dan Nurfitriani, setelah dilakukan penyuluhan banyak pertanyaan yang diajukan mengenai kanker serviks, cara, dan biaya pemeriksaan Pap Smear. Masih banyak wanita yang tidak mengetahui tentang pentingnya pemeriksaan Pap Smear dan di mana tempat melakukan pemeriksaan tersebut (Julaecha dan Nurfitriani, 2019).

Penyuluhan yang dilakukan dalam pengabdian ini diharapkan dapat membuka kepedulian ibu tentang kesehatan reproduksinya, yang nantinya akan mengalahkan rasa malu dan takut yang dirasakan selama ini. Penyuluhan kesehatan yang dilakukan dapat meningkatkan pengetahuan dan sikap antusias atau peduli ibu dalam menjaga kesehatan reproduksinya (Mastikana I., dkk., 2020). Penyuluhan yang dilakukan dapat meningkatkan pengetahuan peserta pengabdian (Sabilu Y., dkk., 2018). Peningkatan pengetahuan peserta pengabdian dari penyuluhan yang dilakukan diharapkan dapat menjadi promosi kesehatan pencegahan kanker serviks (Herlambang dkk, 2019). 
Pemeriksaan Pap Smear dianjurkan pada ibu-ibu yang sudah menikah, setidaknya yang sudah menjalani usia pernikahan selama tiga tahun, dan rutin melakukan pemeriksaan Pap Smear tiap tahun hingga usia 30 tahun. Pemeriksaan Pap Smear dianjurkan rutin dilakukan setiap tiga tahun sekali, selama belum pernah didapatkan hasil Pap Smear yang abnormal, hingga usia 65 tahun Pemeriksaan Pap Smear rutin dilakukan cukup hingga usia 65 tahun

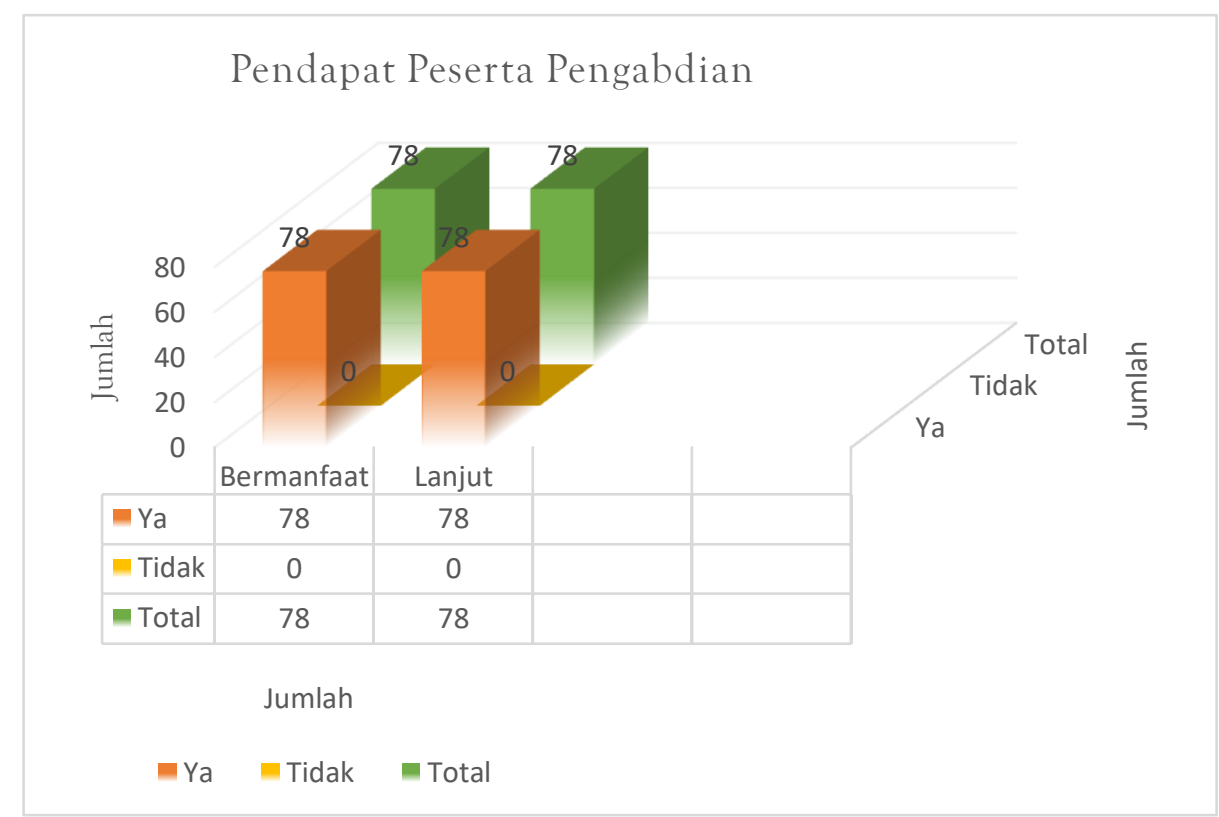

(Andrijono, 2016).

Diagram 2. Pendapat Peserta Pengabdian

Diagram 2 menunjukkan pendapat peserta pengabdian terhadap bermanfaat tidaknya kegiatan pengabdian dan apakah kegiatan serupa perlu dilaksanakan kembali (dilanjutkan) atau tidak. Seratus persen peserta yang dimintai pendapatnya secara acak menyampaikan bahwa kegiatan pengabdian ini sangat bermanfaat, dan perlu dilanjutkan untuk lingkup yang lebih luas di kampus UMY. Penyuluhan kesehatan yang diberikan dapat meningkatkan pengetahuan, sikap, dan motivasi peserta untuk melakukan pemeriksaan IVA untuk deteksi dini kanker serviks

(Sikumbang S.R., http://jurnalmu.poltekkes-mataram.ac.id/index.php/jurnalmu). Peserta pengabdian mengetahui tentang bahaya kanker serviks dan ternyata kanker serviks dapat dideteksi secara dini (Agustina S., 2019). Pengabdian diharapkan dapat menggugah peserta untuk secara rutin melakukan pemeriksaan Pap Smear sesuai anjuran, yaitu setidaknya setiap tiga tahun sekali, bila belum pernah didapatkan hasil Pap Smear yang abnormal. Sejalan dengan himbauan tersebut, namun yang dilakukan pada pemeriksaan IVA, di mana peserta pengabdian akan melakukan pemeriksaan IVA secara teratur sesuai anjuran WHO setiap satu tahun sekali (Ropitasari dkk., 2014).

Pemeriksaan deteksi dini kanker serviks rutin menurunkan angka kejadian kanker serviks dan menurunkan angka kematian oleh kanker serviks. Peningkatan kesadaran masyarakat terhadap faktor risiko kanker serviks dengan melakukan upaya pencegahan dengan deteksi dini secara periodik, diharapkan dapat menurunkan angka kejadian kanker serviks di wilayah tersebut (Muhartono dkk., 2016).

\section{Simpulan}

Pengabdian masyarakat "Edukasi Pencegahan Kanker Serviks secara Primer dan Sekunder bagi Dosen di FKIK UMY" berjalan lancar dan diikuti dengan antusias oleh para dosen wanita FKIK UMY, bahkan peserta bertambah dengan hadirnya ibu-ibu dosen non-FKIK UMY. 
Kegiatan pengabdian dengan melakukan minisimposium dan tanya jawab, pemeriksaan Pap Smear, dan penyuntikan vaksinasi HPV dirasakan bermanfaat oleh para peserta pengabdian. Dengan mengingat manfaat bagi kesehatan, para peserta yang dicatat pendapatnya secara acak mengharapkan bisa dilakukan kegiatan serupa dengan lingkup yang lebih luas, mungkin mencakup prodi atau fakultas lain dalam lingkup kampus UMY.

\section{Ucapan Terima Kasih}

Ucapan terimakasih yang sebesar-besarnya kami sampaikan kepada:

1. Fakultas Kedokteran dan Ilmu Kesehatan, Universitas Muhammadiyah Yogyakarta (FKIK UMY), yang telah membantu pendanaan pelaksanaan pengabdian ini.

2. dr. Agus Widiyatmoko, Sp.PD., M.Sc., selaku Direktur RS AMC Muhammadiyah Yogyakarta, yang telah mengijinkan sebagai tempat pelaksanaan kegiatan pemeriksaan Pap Smear dan penyuntikan vaksinasi HPV.

3. dr. Alfaina Wahyuni, SpOG, M.Kes, yang telah membantu terlaksananya pemeriksaan Pap Smear dan penyuntikan vaksinasi HPV.

4. dr. Indrayanti, Sp.PA., yang telah membantu sebagai pemateri 2 dan pemeriksa sampel Pap Smear.

5. Dokter-dokter IGD RS AMC Muhammadiyah Yogyakarta, yang telah membantu pelaksanaan penyuntikan vaksinasi HPV.

6. Panitia ICMHS 4 ICosi 2020 FKIK UMY, yang telah membantu pelaksanaan pengabdian masyarakat ini.

\section{Daftar Pustaka}

Agustina S. 2019. Penyuluhan Kanker Serviks Dan Pemeriksaan Kesehatan Melalui Tes Iva Di Cipayung Jakarta Timur. Jurnal Pelayanan dan Pengabdian Masyarakat; 3(1): 49-53.

Andrijono. 2016. Kanker Serviks. Edisi ke-5. Badan Penerbit Fakultas Kedokteran Universitas Indonesia. Jakarta.

Dewi M. 2017. Sebaran Kanker di Indonesia, Riset Kesehatan Dasar 2007. Indonesian Journal of Cancer; 11(1): 1-8.

Hari Kanker Sedunia. Website: https://www.kemkes.go.id/article/view/19020100003/harikanker-sedunia-2019.html. Diakses pada tanggal 9 Oktober 2020.

Herlambang, Kusdiyah E., Iskandar M.M. 2019. Peningkatan Pengetahuan Wanita Tentang Kanker Serviks Dan Pemeriksaan Pap Smear Sebagai Skrining Awal. Medic; 2(1): 25-28.

Julaecha dan Nurfitriani. 2019. Deteksi Dini Kanker Serviks Dengan Pemeriksaan Serviks Di Kelurahan Buluran Kenali Kota Jambi Tahun 2017. Jurnal Abdimas Kesehatan (JAK); 1(1): 56-60.

Kementerian Kesehatan RI. 2019. Profil Kesehatan Indonesia 2018. Jakarta. Website: http://www.kemkes.go.id. Diakses pada tanggal: 9 Oktober 2020.

Kementerian Kesehatan RI. 2020. Profil Kesehatan Indonesia 2019. Jakarta. Website: http://www.kemkes.go.id. Diakses pada tanggal 9 Oktober 2020.

Mariana R. 2019. Strategi Komunikasi Deteksi Dini Kanker Serviks di Kota Bandung. MediaTor; 12(1): 1-14.

Mastikana I., Sari E.P., Nasution E.S., Karlina N., Ra’ad S.T., Juni S.M., Adhis I.P. 2020. Penyuluhan Deteksi Dini Kanker Leher Rahim/Kanker Serviks Serta Pemeriksaan Iva Di Wilayah Kerja Puskesmas Sei Langkai Batu Aji Kota Batam. Communnity Development Journal; 1(2): 130-135. 
Muhartono, Saftarina F., Windarti I. 2016. Pelatihan Deteksi Dini Kanker Serviks Dengan Metode Pap Smear Di Kotabumi Lampung Utara. JPM Ruwa Jurai; 2(1): 5-8.

Pusat Data dan Informasi. 2015. Situasi Penyakit Kanker. Dalam: Data dan Informasi Kesehatan. Kementerian Kesehatan RI. Jakarta. Buletin-kanker.pdf. Website: https://www.kemkes.go.id. Diakses pada tanggal 7 Oktober 2020.

Ropitasari, Soetrisno, MulyaniS., Saddhono K. 2014. Deteksi Dini Kanker Leher Rahim Melalui Tes Iva Di Puskesmas Jaten Ii Kabupaten Karanganyar. Vol 3 No 1 Nov 2014: 1-5.

Sabilu Y., Lisnawaty, Pratiwi A.D. 2018. Deteksi Dini Kanker Serviks Dengan Pemeriksaan IVA (Inspeksi Visual Asama Asetat) Pada Wanita Usia Subur Di Rw 003 Kelurahan Anduonohu Kota Kendari. Jurnal Ilmiah Praktisi Kesehatan Masyarakat Sulawesi Tenggara; 3(1): 70-75.

Sembiring R. dan Panggabean R.D.E. 2020. Pendidikan Kesehatan Tentang Deteksi Dini Kanker Cerviks Di Klinik Mariana. Jurnal Pengabdian Masyarakat (Kesehatan); 2(1): 1-5.

Sikumbang S.R. Pengaruh Penyuluhan Kesehatan Terhadap Pengetahuan, Sikap Dan Motivasi Tentang IVA. Jurnal Midwifery Update (MU) http://jurnalmu.poltekkesmataram.ac.id/index.php/jurnalmu e-ISSN: 2684-8511 (Online): 90-102. Diakses pada tanggal: 6 oktober 2020.

Syaiful, Tarigan F.L., Zuska F. 2018. Skrining Kanker Serviks Dengan Pemeriksaan Pap Smear Pada Profesi Bidan Di Rumah Sakit Tk Ii Putri Hijau Medan Tahun 2017. Jurnal Riset Hesti Medan; 3(2): 1-15.

Wahidin M. 2015. Deteksi Dini Kanker Leher Rahim dan Kanker Payudara di Indonesia 20072014. Dalam: Data dan Informasi Kesehatan. Kementerian Kesehatan RI. Jakarta. Buletinkanker.pdf. Website: https://www.kemkes.go.id. Diakses pada tanggal 7 Oktober 2020. 